\title{
Carbon dots hybrid for dual fluorescent detection of microRNA-21 integrated bioimaging of MCF-7 using a microfluidic platform
}

\author{
Somayeh Mohammadi ${ }^{1}$, Abdollah Salimi ${ }^{1,2^{*}}$, Zohreh Hoseinkhani ${ }^{3}$, Foad Ghasemi ${ }^{4}$ and Kamran Mansouri ${ }^{3}$
}

\begin{abstract}
Background: MicroRNAs have short sequences of 20 25-nucleotides which are similar among family members and play crucial regulatory roles in numerous biological processes, such as in cell development, metabolism, proliferation, differentiation, and apoptosis.

Results: We reported a strategy for the construction of a dual-emission fluorescent sensor using carbon dots (CDs) and confirmed their applications for ratiometric microRNA-21 sensing and bioimaging of cancer cells in a microfluidic device. The composition of blue CDs (B-CDs) and yellow CDs (Y-CDs) depicts dual-emission behavior which is centered at 409 and $543 \mathrm{~nm}$ under an excitation wavelength of $360 \mathrm{~nm}$. With increasing microRNA-21 concentration, the robust and specific binding of DNA probe functionalized B-CDs to complementary microRNA-21 target induced perturbations of probe structure and led to changing fluorescence intensity in both wavelengths. Consequently, the ratio of turn-on signal to turn-off signal is greatly altered. With monitoring of the inherent ratiometric fluorescence variation $\left(\Delta \mathrm{F}_{540 \mathrm{~nm}} / \Delta \mathrm{F}_{410 \mathrm{~nm}}\right)$, as-prepared $\mathrm{BY}$-CDs were established as an efficient platform for ratiometric fluorescent microRNA-21 sensing, with a wide linear range of $0.15 \mathrm{fM}$ to $2.46 \mathrm{pM}$ and a detection limit of $50 \mathrm{aM}$.
\end{abstract}

Conclusions: Furthermore, the proposed assay was applied for detecting microRNA-21 in dilute human serum samples with satisfactory recovery and also in MCF-7 cell lines in the range 3000 to 45,000 (cell mL ${ }^{-1}$ ) with a detection limit (3 cells in $10 \mu \mathrm{L}$ ), demonstrating the potential of the assay for clinic diagnosis of microRNA-associated disease. More importantly, the images revealed that MCF-7 cells well labeled with BY-CDs could exhibit the applicability of the proposed microfluidic system as an effective cell trapping device in bioimaging.

Keywords: Ratiometric fluorescence, Microfluidic, MicroRNA-21, Dual emissive assay, Carbon dots, Cell imaging

*Correspondence: absalimi@uok.ac.ir

1 Department of Chemistry, University of Kurdistan,

66177-15175 Sanandaj, Iran

Full list of author information is available at the end of the article

(c) The Author(s) 2022. Open Access This article is licensed under a Creative Commons Attribution 4.0 International License, which permits use, sharing, adaptation, distribution and reproduction in any medium or format, as long as you give appropriate credit to the original author(s) and the source, provide a link to the Creative Commons licence, and indicate if changes were made. The images or other third party material in this article are included in the article's Creative Commons licence, unless indicated otherwise in a credit line to the material. If material is not included in the article's Creative Commons licence and your intended use is not permitted by statutory regulation or exceeds the permitted use, you will need to obtain permission directly from the copyright holder. To view a copy of this licence, visit http://creativecommons.org/licenses/by/4.0/. The Creative Commons Public Domain Dedication waiver (http://creativeco mmons.org/publicdomain/zero/1.0/) applies to the data made available in this article, unless otherwise stated in a credit line to the data. 


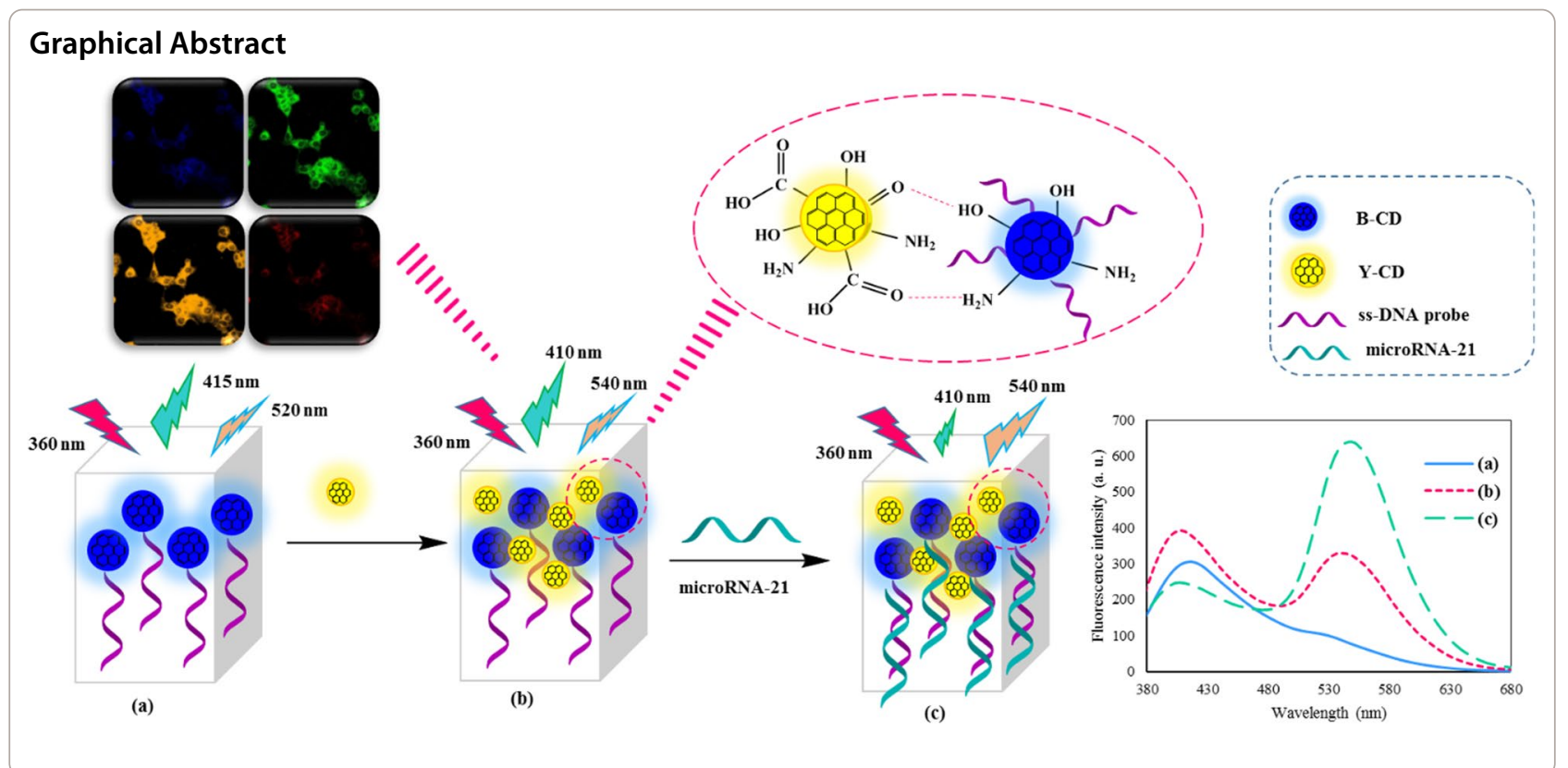

\section{Background}

MicroRNAs, a class of endogenous single-stranded non-coding RNAs, have regulated gene activity in cell development [1], metabolism [2], proliferation [3], differentiation [4], and apoptosis [5]. There is a recognizable connection among dysregulation of microRNA expressions and numerous genetic disorders, such as diabetes [6], neurological diseases [5], viral infections [7], strokeinduced tissue injury [8], and cancers [9]. For instance, microRNA-21 is a robust oncogenic microRNA, not only does its overexpression contribute to a remarkable role in the differentiation, development, and apoptosis of normal cells and course in the characterization of cancer phenotype, but it also can be utilized as a diagnosis, staging, progression and prognosis biomarker for different human malignancies $[10,11]$. Determination of microRNAs has encountered numerous challenging tasks owing to their short and extreme similarity of sequences, low abundance in whole RNA samples, and extensive dynamic range [12].

The conventional microRNAs detection systems, including polymerase-chain-reaction (PCR) [13], northern blotting [14], and microarray [15], have been broadly employed as reliable and gold-standard procedures for microRNA profiling but these approaches suffer from the restrictions of low sensitivity, complicated operation, time-consuming methodology, and costly equipment, which confine their practical usage $[16,17]$.

Developing effective approaches for sensitive microRNAs determination in clinical diagnosis is worth striving for. Ratiometric sensing methods, in which the detection relies on the intensity ratio of emission wavelengths instead of one emission wavelength as signal outputs, have become an ideal approach to quantify target analytes. The intensity ratio-based assays can enable enhanced analytical performance because the ratio of two signals is not affected by the interference factors, such as path length, background light, and scattering by self-calibration [18]. Numerous ratiometric electrochemistry [19, 20], electrochemiluminescence [21], chemiluminescence [22], surface-enhanced Raman spectroscopy [23], and fluorescence [24-26] methods have been reported for extremely accurate and sensitive quantification of microRNA. Among them, ratiometric fluorescent procedures have become increasingly widespread in analytical usage because of their intrinsic benefits such as quick response, high sensitivity, and relatively inexpensive. The detection limit in the pM range was not sufficient to be exploited for the determination of microRNAs in real samples [26, 27]. Therefore, the construction of highly sensitive ratiometric fluorescence methods for microRNAs detection to make them practical in clinical diagnosis is significant [26].

Recently, with the remarkable attainments of nanotechnology, nanomaterial-based biosensors have been significantly expanded owing to the distinctive electronic, optical, and catalytic features of the nanomaterials, which enable the signal amplification to attain high sensitivity $[28,29]$. Recently, numerous functional nanomaterials, such as graphene [30], CDs [31], $\mathrm{MoS}_{2}$ nanosheets [32], $\mathrm{MnO}_{2}$ [31], Conjugated polyelectrolytes [33], and metal-organic framework (MOF) [24], were employed as 
carriers and quenchers to decrease the background signal and enhance the signal-to-noise ratio [26]. Nanomaterials have contributed to noteworthy enhancements in the design and expansion of ratiometric fluorescence probes, because of the cooperation between nanomaterial and ratiometric fluorescence assay [29].

There have been essential recent attention to the development of nanomaterials with high fluorescent signal for optical imaging and sensing applications. An ideal fluorescent agent should be biocompatible, non-toxic, bright, and photostable against photobleaching. The poor photostability, relatively short lifetimes, narrow excitation ranges, and broad emission spectra of fluorescence dyes confines their practical usages in long-term bioimaging. Quantum dots (QDs) exhibit numerous improved optical features, like high brightness and long-term photo-stability, being desirable for biological uses rather than organic dyes. While they have some drawbacks, including the low solubility in water and toxicity restricted their applications in bioimaging [34-36]. CDs, as a member of newly emerging photoluminescent zero-dimensional carbonaceous nanomaterials, offer various improved features, such as convenient synthesis, good water-solubility, adjustable emission spectrum controlled by altering the synthesis conditions, multicolored emissions, and inherent biocompatibility [37, 38]. Therefore, these fluorescent carbon nanomaterials can be appropriate substitutes for fluorescent dyes and semiconductor QDs owing to their unique capability in the field of cell analysis [38].

Biomedical research principally concentrates on the development of effective technologies, like biosensors, image processing, and disease diagnosis [39]. Microfluidic technologies have the potential to develop a capable tool in cellular experiments since it offers distinctive capabilities, like high-throughput potential under various situations, less sample and reagent need, easy construction, and the capability for in vivo and in vitro cellular imaging. Another benefit of microfluidics is the capability to be efficiently combined with other analytical techniques, such as optical detection, electrochemistry, and mass spectrometry. Profited from the progress of microfluidic culture and fluorescence labeling methods, chips integrated with fluorescent devices have converted to a robust tool for cell investigation [11].

Herein, we introduced a new ratiometric nanohybrid fluorescent probe for the detection of microRNA-21 with dual-colored CDs (blue CDs and yellow CDs) as fluorophores. This distinctive combination of Y-CDs and B-CDs supplied two discrete and stable emission signals (409 and $543 \mathrm{~nm}$ ) under the same excitation wavelength $(360 \mathrm{~nm})$. In the presence of microRNA-21, the emission signal in $409 \mathrm{~nm}$ was decreased while fluorescence intensity in $543 \mathrm{~nm}$ was increased. Great potential for distinguishing between complementary and single-base mismatch microRNA strands has confirmed the great selectivity of the nanosensor for gene mutation assessment. More importantly, the excellent analytical performance of the present assay has been verified in the complex biological medium of cancer cells. The suggested system has been utilized for imaging MCF-7 cancer cells with great reliability and contrast. Moreover, the dual-colored CDs have been assessed as a fluorescent nanoprobe for cellular imaging using a microfluidic system. Taken together, the present procedure enables a great device for microRNA-related biological research.

\section{Experimental section}

\section{Materials and instruments}

All of the DNA, microRNA oligonucleotide sequences were obtained from BIONEER, Global Genomics Partner (http://www.bioneer.com), and purified using HPLC. Their sequences were as follows:

DNA probe: [C6 Amine] TCAACATCAGTCTGA TAAGCTA

MicroRNA-21 target: UAGCUUAUCAGACUGAUG UUGA

1 base mismatched microRNA-21: UAGCUUAUC ACACUGAUGUUGA

MicroRNA-155 target: UUAAUGCUAAUCGUG AUAGGGGU

1 base mismatched microRNA-155: UUAAUGCUA CUCGUGAUAGGGGU

1-Ethyl-3-(3-dimethyl aminopropyl) carbodiimide hydrochloride (EDC), and N-hydroxy succinimide (NHS) were purchased from Abcam Company (Cambridge, UK, http:// www.Abcam.com). Dialysis bag (molecular weight cut off $=1000 \mathrm{KDa}$ ) was obtained from Sigma-Aldrich (https:// www.sigmaaldrich.com). O-phenylenediamine (O-PD), 2-Aminoterephthalic acid, and DMF were ordered from Merck Company (Darmstadt, Germany, http://www.merck. com). The human breast cancer cell line include MCF-7 was acquired from the national cell bank of Iran (Pasteur Institute of Iran, Tehran) and was cultured by confirmed protocols. The TEM images were performed on an H600 TEM (Hitachi, Japan) for specifying of size and shape of prepared CDs. The fluorescence emission spectra were achieved on a Perkin Elmer fluorescence LS55 spectrophotometer (Germany) with the tool settings as follows: $\lambda_{\text {ex }}=360 \mathrm{~nm}$ (slit $10 \mathrm{~nm}$ ), $\lambda_{\mathrm{em}}=370-670 \mathrm{~nm}$ (slit $10 \mathrm{~nm}$ ), PMT detector voltage $=670 \mathrm{~V}$. Laser scanning confocal microscope (Nikon, ECLIPSE, Ti, Japan) was utilized for relative cell imaging. 

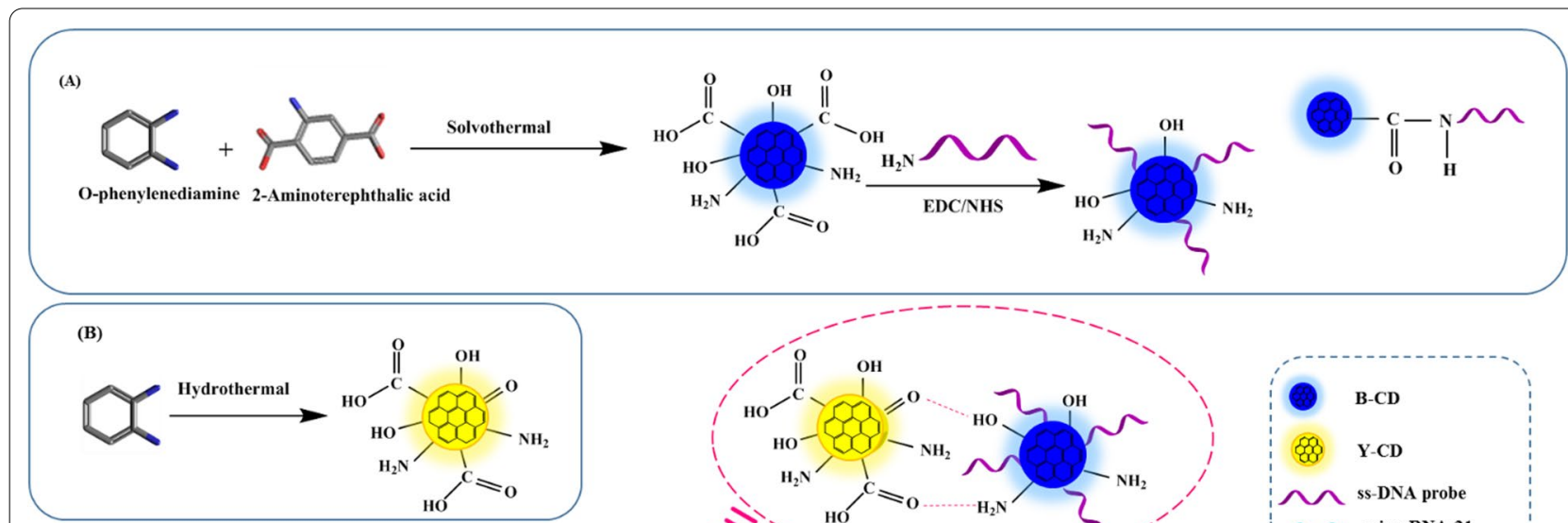

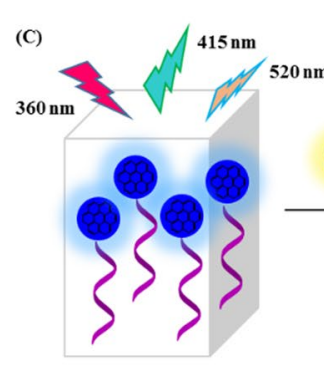

(a)

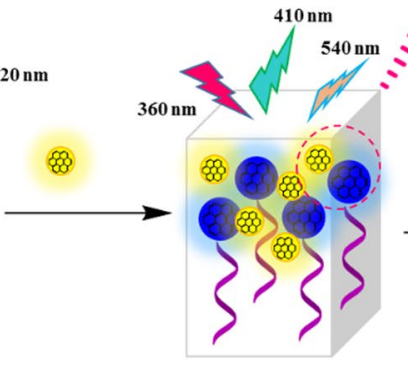

(b)

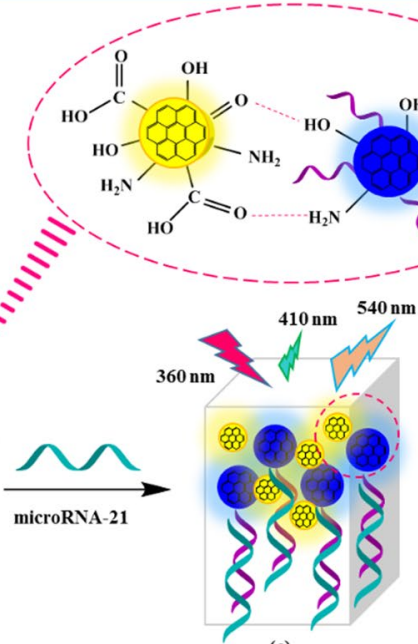

(c)
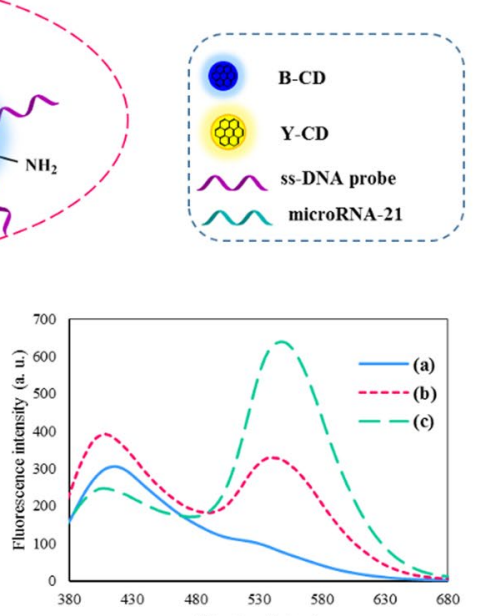

Wavelength (nm)

Scheme 1 The schematic illustration of the dual-emissive optical method for microRNA-21 detection; synthesis and functionalization of B-CDs (A), synthesis of $\mathrm{Y}-\mathrm{CDs}(\mathbf{B})$, and procedure of microRNA-21 detection

\section{Synthesis of blue-emitting carbon dots (B-CDs)}

$\mathrm{B}-\mathrm{CD}$ was synthesized using the solvothermal route. The mixture of O-phenylenediamine (OPDA) $(50.0 \mathrm{mg}$, $0.46 \mathrm{~mol})$ and 2-Aminoterephthalic acid $(75.0 \mathrm{mg}$, $0.41 \mathrm{~mol}$ ) was first dissolved in a $30 \mathrm{~mL}$ mixed solvent of DMF and water with a volume ratio of $5 / 25$. Then, the mixed solution was transferred to a Teflon-lined stainless autoclave and heated in an air-circulating oven at $120^{\circ} \mathrm{C}$ for $24 \mathrm{~h}$ (Scheme 1A). Subsequently, the autoclave was cooled down to room temperature naturally. The orange solution was collected by centrifugation $(3500 \mathrm{rpm}$ for $10 \mathrm{~min}$ ) to remove large particles. Then the upper solution was put into a dialysis membrane (1000 Da, molecular weight cut-off) against deionized water to remove some free molecules. The concentration of purified B-CDs solution was about $1.15 \mathrm{mg} \cdot \mathrm{mL}^{-1}$ as measured using the dry weight analysis procedure. The final solution was stored in a refrigerator at $4{ }^{\circ} \mathrm{C}$ for further research.

\section{Synthesis of yellow emitting carbon dots ( $\mathrm{Y}-\mathrm{CDs}$ )}

Y-CDs were synthesized according to a previously reported method [40] with proper modification. Briefly, $500 \mathrm{mg}$ of OPDA was dissolved in $50 \mathrm{~mL}$ of water
(Scheme 1B). Subsequently, the mixed solution was put in a Teflon-lined autoclave and heated at $180{ }^{\circ} \mathrm{C}$ for $12 \mathrm{~h}$, then cooled to room temperature. The dark yellow product was centrifuged at $3500 \mathrm{rpm}$ for $5 \mathrm{~min}$ to remove solid particles and collect the supernatants. The supernatants were dialyzed against distilled water at $4{ }^{\circ} \mathrm{C}$ for $24 \mathrm{~h}$ for further purification. The final solution $\left(1.4 \mathrm{mg} \mathrm{mL}^{-1}\right)$ was kept at $4{ }^{\circ} \mathrm{C}$ for further usage.

\section{Ratiometric fluorescence detection of microRNA-21}

The B-CDs were functionalized with a DNA probe performed through carbodiimide-activated coupling between $\mathrm{B}$-CDs and $\mathrm{NH}_{2}$-modified DNA probe. In a typical process, $100 \mu \mathrm{L}$ ethyl-3-(3-dimethyl aminopropyl) carbodiimide (EDC) $\left(0.01 \mathrm{~mol} \mathrm{~L}^{-1}\right)$ and $100 \mu \mathrm{L}$ N-hydroxysuccinimide (NHS) $\left(0.01 \mathrm{~mol} \mathrm{~L}^{-1}\right)$ were added to $1.0 \mathrm{~mL}$ of the aforementioned CDs $\left(1.15 \mathrm{mg} \mathrm{mL}^{-1}\right)$ and kept at room temperature for $1 \mathrm{~h}$. Then, $50 \mu \mathrm{L}$ DNA probe $(1.0 \mu \mathrm{M})$ was added to this solution and kept in the refrigerator for $24 \mathrm{~h}$ (Scheme 1A). Excessive EDC and NHS were removed by dialysis [41]. The quantitative detection of microRNA-21 using the BY-CDs method was achieved as follows: To construct the dual emission probe, B-CDs and Y-CDs were mixed in 3 different volume ratios $(2: 1,1: 1,1: 2)$, and diluted with $270 \mu \mathrm{L}$ of 
ultrapure water. Then different microRNA concentrations were added to above sensing system. After incubation for $20 \mathrm{~min}$, the fluorescence signal was recorded in the 370-670 $\mathrm{nm}$ emission range under excitation at $360 \mathrm{~nm}$ (Scheme 1C). Each measurement was repeated three times.

\section{Cell culture and cytotoxicity assays}

The MCF-7 cells were cultured in DMEM containing 10\% (v/v) fetal bovine serum (FBS), $1 \%(\mathrm{v} / \mathrm{v})$ penicillin at $37^{\circ} \mathrm{C}$ in a humid environment of $5 \% \mathrm{CO}_{2}$. MTT assay was applied to evaluate the cytotoxicity of BY-CDs. MCF-7 cells were cultured for $24 \mathrm{~h}$ under the aforementioned situations. After eliminating the culture medium, various amounts of BY-CDs $\left(0,0.05,0.1,0.2,0.5,1.0 \mathrm{mg} \mathrm{mL}^{-1}\right)$ were added into 96-well plates and were kept in an incubator for another $24 \mathrm{~h}$. After that, the culture medium was separated. Then $200 \mu \mathrm{L}$ of fresh DMEM containing $10 \%$ MTT $(20 \mu \mathrm{L})$ was added to each well. After $3 \mathrm{~h}$, the supernatant solution was substituted with $100 \mu \mathrm{L}$ of DMSO to dissolve MTT. Following this, the 96-well was shaken at room temperature for $15 \mathrm{~min}$. Finally, the optical density of each well was recorded at 545/630 nm with a microplate reader. Cell viability (\%) was calculated using the following equation:

Cell viability $(\%)=\left(\mathrm{OD}_{\text {treated }} / \mathrm{OD}_{\text {control }}\right) \times 100 \%$.

\section{Imaging of microRNA-21 in fixed MCF-7 cell lines}

The cell imaging tests were verified using MCF-7 cells on a confocal laser scanning microscope (CLSM) with a $40 \times$ objective. The imaging potential of BY-CDs fluorescent probe for microRNA detection in cells was evaluated using MCF-7 cancer cells. Briefly, $1 \mathrm{~mL}$ of MCF-7 cell suspensions were seeded in 6 -well culture dishes at a density of $7 \times 10^{3}$ cells at $37{ }^{\circ} \mathrm{C}$ in a humid environment containing $5 \% \mathrm{CO}_{2}$ for $24 \mathrm{~h}$. Then the medium was substituted by a fresh medium containing $0,0.5$, and $1.0 \mathrm{mg} \mathrm{mL}{ }^{-1}$ BY-CDs, the cells have been incubated for $24 \mathrm{~h}$. After washing twice with PBS, the cells were fixed with formaldehyde $4 \%$ and then were washed thrice with PBS.

\section{Construction of the microfluidic device}

Firstly, a silicon mold was constructed by the Reactive Ion Etching (RIE) method. Polydimethylsiloxane (PDMS) is the most common substance for microfluidic fabrication. A mixture of PDMS prepolymer and curing agent (10:1) was cast onto the pre-etched silicon mold and cured at $80{ }^{\circ} \mathrm{C}$ for $12 \mathrm{~h}$. After patterning of a PDMS substrate by replica molding from a silicon mold, the PDMS replica surface and a glass substrate were activated with reactive oxygen plasma and bonded together, and then permanently sealed to construct channels [42].

\section{Results and discussion Characterization of CDs}

In this study, a CDs-based ratiometric fluorescent probe was constructed for the detection of microRNA-21 as a target. The formation of CDs was proved by SEM image, which is displayed in Additional file 1: Fig. S1. TEM images and the size distribution histograms of B-CDs and $\mathrm{Y}-\mathrm{CDs}$ are displayed in Fig. 1A-D which revealed that the $\mathrm{B}-\mathrm{CDs}$ and $\mathrm{Y}-\mathrm{CDs}$ are sphere-shaped and have a mediocre diameter of $2.25 \pm 0.94$ and $6.47 \pm 1.87 \mathrm{~nm}$, respectively. The CDs are further characterized by FTIR. In detail, as shown in Fig. 1E, the FTIR spectra of Y-CDs and $\mathrm{B}-\mathrm{CDs}$ exhibit a characteristic broadband between 3100 and $3600 \mathrm{~cm}^{-1}$, which are ascribed to stretching vibrations of $\mathrm{N}-\mathrm{H}$ and $\mathrm{O}-\mathrm{H}$. The band appears at $2800-2950 \mathrm{~cm}^{-1}$ is attributed to stretching vibrations of $\mathrm{C}-\mathrm{H}$. The band that is very common to ascribe carboxylic/carbonyl functional groups from CDs, is a band in the range of $1600-1770 \mathrm{~cm}^{-1}$ as a piece of evidence from the vibrational stretching of $\mathrm{C}=\mathrm{O}$. The peaks at 1027 and $1207 \mathrm{~cm}^{-1}$ can be ascribed to the $\mathrm{C}-\mathrm{O}$ and $\mathrm{C}-\mathrm{N}$ stretching frequencies, respectively. The vibration band at $1389 \mathrm{~cm}^{-1}$ demonstrated the presence of an aromatic $\mathrm{C}=\mathrm{C}$ group [43]. These results reveal that $\mathrm{Y}-\mathrm{CDs}$ and B-CDs were comprised of aromatic structures and had amine and carboxyl groups on their surface.

\section{Optical properties of CDs}

The optical properties of $\mathrm{B}-\mathrm{CDs}$ and $\mathrm{Y}$-CDs and their mixtures were studied by a recording UV-vis absorption and fluorescence (FL) spectra. First, as predicted, all the spectra display two main absorbance peaks. One of the peaks is a strong absorption in the UV region, which is ascribed to the typical $\pi-\pi^{*}$ transition of the aromatic $\mathrm{sp}^{2}$ core domain. Moreover, the absorption peak at $\approx 300 \mathrm{~nm}$ is attributed to $\mathrm{n}-\pi^{*}$ transition of surface functional groups with lone pairs electron to the $\pi^{*}$ orbital of the $\mathrm{sp}^{2}$ carbon domain (Fig. 2A) [44]. The absorbance spectra of $\mathrm{B}-\mathrm{CD}$, DNA probe, and B-CD-DNA probe attained in Fig. 2B propose the successful immobilization of DNA probe onto B-CD surface. The UV-vis absorption peaks were observed at about 270 and $305 \mathrm{~nm}$ for $\mathrm{B}-\mathrm{CD}$ and $260 \mathrm{~nm}$ for DNA probe. The covalent interaction between $\mathrm{B}-\mathrm{CD}$ and DNA probe led to increasing the peaks at around 270 and $305 \mathrm{~nm}$ that confirming the successful loading of DNA probe on B-CD. Moreover, the successful immobilization of the DNA probe on $\mathrm{B}-\mathrm{CD}$ was verified by electrochemical impedance spectroscopy (EIS). As shown in Additional file 1: Fig. S2, the bare GCE displayed a small semicircle, while the resistance increased for the electrode immobilized with B-CD. For the $\mathrm{BCD}$-DNA probe loaded on an electrode, a further 

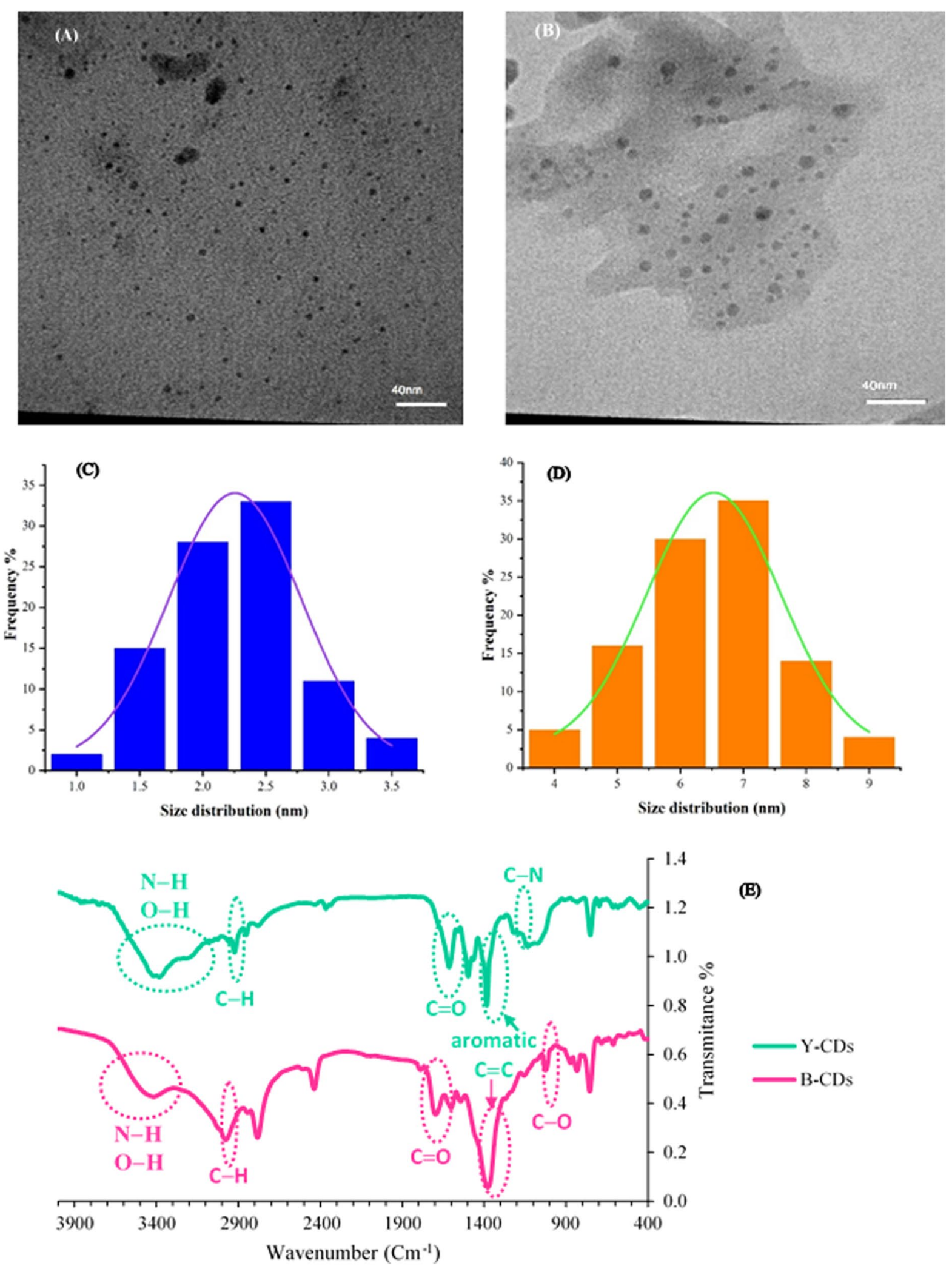

Fig. 1 TEM images and the size distribution histograms of B-CDs $(\mathbf{A}, \mathbf{C})$ and $Y-C D s(\mathbf{B}, \mathbf{D})$; The FTIR spectra of Y-CDs and B-CDs $(\mathbf{E})$ 

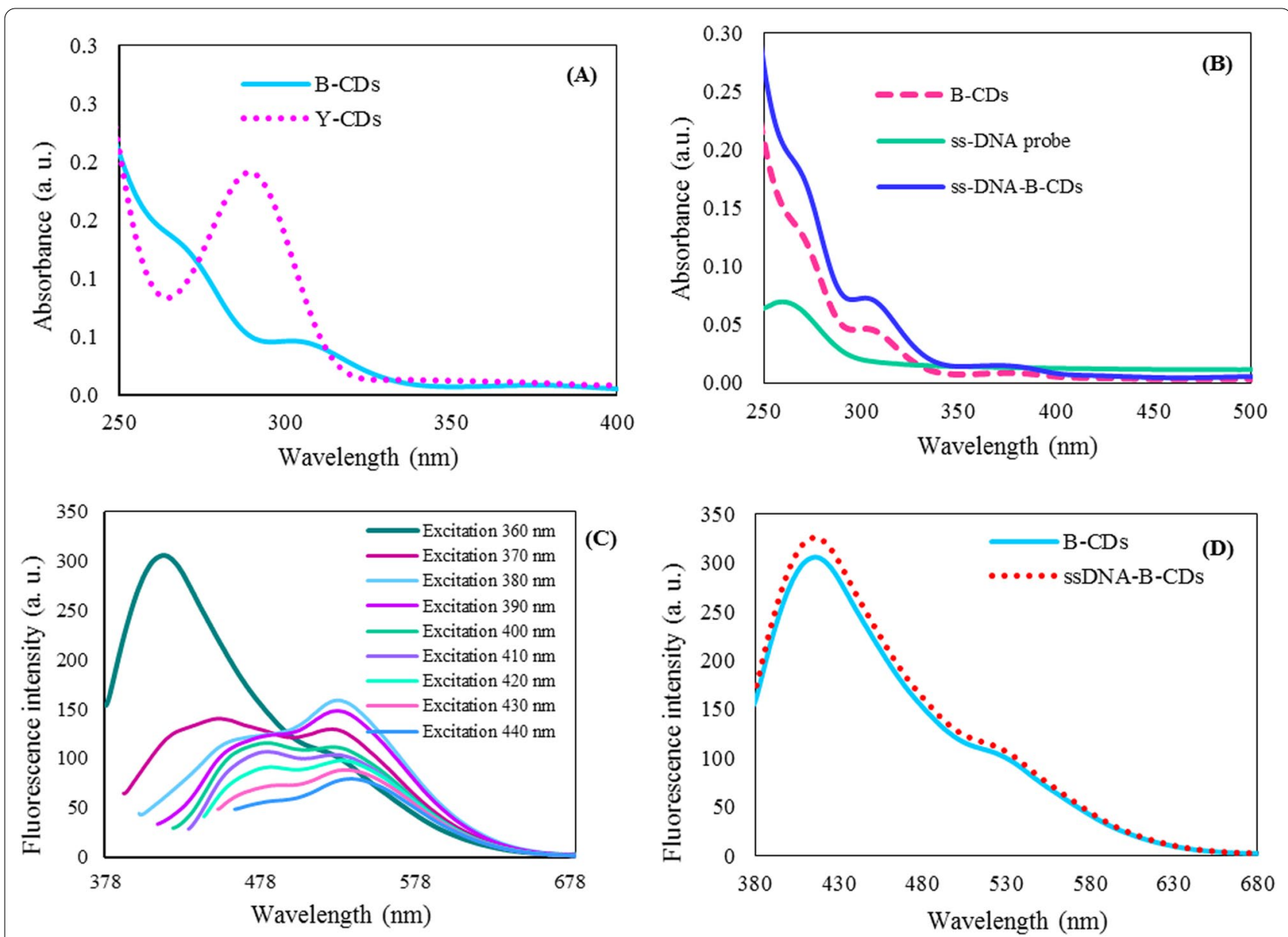

Fig. 2 UV-Vis absorption of B-CD and Y-CD (A); UV-vis absorption of B-CD, DNA probe and B-CD-DNA probe (B); Fluorescence spectra of B-CDs at different excitation wavelengths from 360 to $440 \mathrm{~nm}$ (C); Fluorescence spectra of B-CD and DNA probe functionalized B-CD (D)

increase in resistance was observed, which confirmed the B-CD modification with the DNA probe.

CDs usually possess the excitation wavelength-dependent emission, as presented in Fig. $2 \mathrm{C}$, the prepared $\mathrm{B}-\mathrm{CDs}$ reveal excitation wavelength-dependent emission behavior, displaying various emission wavelengths ranging from 415 to $485 \mathrm{~nm}$ and 520 to $540 \mathrm{~nm}$ at excitations from 360 to $440 \mathrm{~nm}$. It seems that the excitation-dependent emission is originated from various fluorescence centers and complex energy levels of CDs, affecting their bandgaps $[44,45]$. The mixture of B-CDs and Y-CDs (BYCDs) showed a fluorescence spectrum with emission peaks at $410 \mathrm{~nm}$ and $540 \mathrm{~nm}$ upon excitation at $360 \mathrm{~nm}$ (Additional file 1: Fig. S3). The conjugated aromatic $\pi$ structures and also hydrogen bonding among carboxylic acid, carbonyl functional groups, and $-\mathrm{NH}_{2},-\mathrm{OH}$ on CDs may enhance the rigidity and lead to the shift of the absorption and emission wavelengths [46]. In the case of fluorescence emission, an increase in fluorescence signal of $\mathrm{B}-\mathrm{CDs}$ is realized after DNA probe functionalization rooted in alterations in the steric and electronic features, likely created by the enhance of nitrogen moieties after modification with DNA probe in addition to enhancing its rigidity [47] (Fig. 2D).

\section{Optimization of experimental conditions}

To improve the detection performance for target microRNA-21, the experimental conditions including B-CDs -Y-CDs ratio, DNA probe concentration, and incubation time were optimized using fluorescence intensity ratio defined as $\Delta \mathrm{F}_{540} / \Delta \mathrm{F}_{410}$. To construct the dual emission probe, $\mathrm{B}-\mathrm{CDs}$ and $\mathrm{Y}$-CDs were mixed in the different volume ratios of $2: 1,1: 1$, and 1:2 (B-CDs: Y-CDs), and various microRNA-21 concentrations in the range of 0.15-6.76 fM were added to the prepared solution. Upon excitation of $360 \mathrm{~nm}$, blue-emitting CDs and yellowemitting CDs exhibited a maximum emission at 415 and $435 \mathrm{~nm}$, respectively. The combination of two types of CDs led to a dual emission photoluminescence spectrum under a 
single wavelength excitation (360 nm) at 410/543 nm. The blue shifting the maximum emission wavelength $\sim 410 \mathrm{~nm}$ may originate from increasing particle size [48]. As shown in Fig. $3 \mathrm{~A}$, the $\Delta \mathrm{F}_{540} / \Delta \mathrm{F}_{410}$ ratio was the best when using a 1:1 volume ratio of $\mathrm{B}-\mathrm{CDs}$ and $\mathrm{Y}$-CDs in the system.
DNA probe is one such material that has attracted wide attention owing to its physical features, various structural engineering abilities, low-cost synthesis procedure, and unparalleled customizability for exactly arranging target-binding sites at the nanostructures. These features make the DNA probe a superb option for the

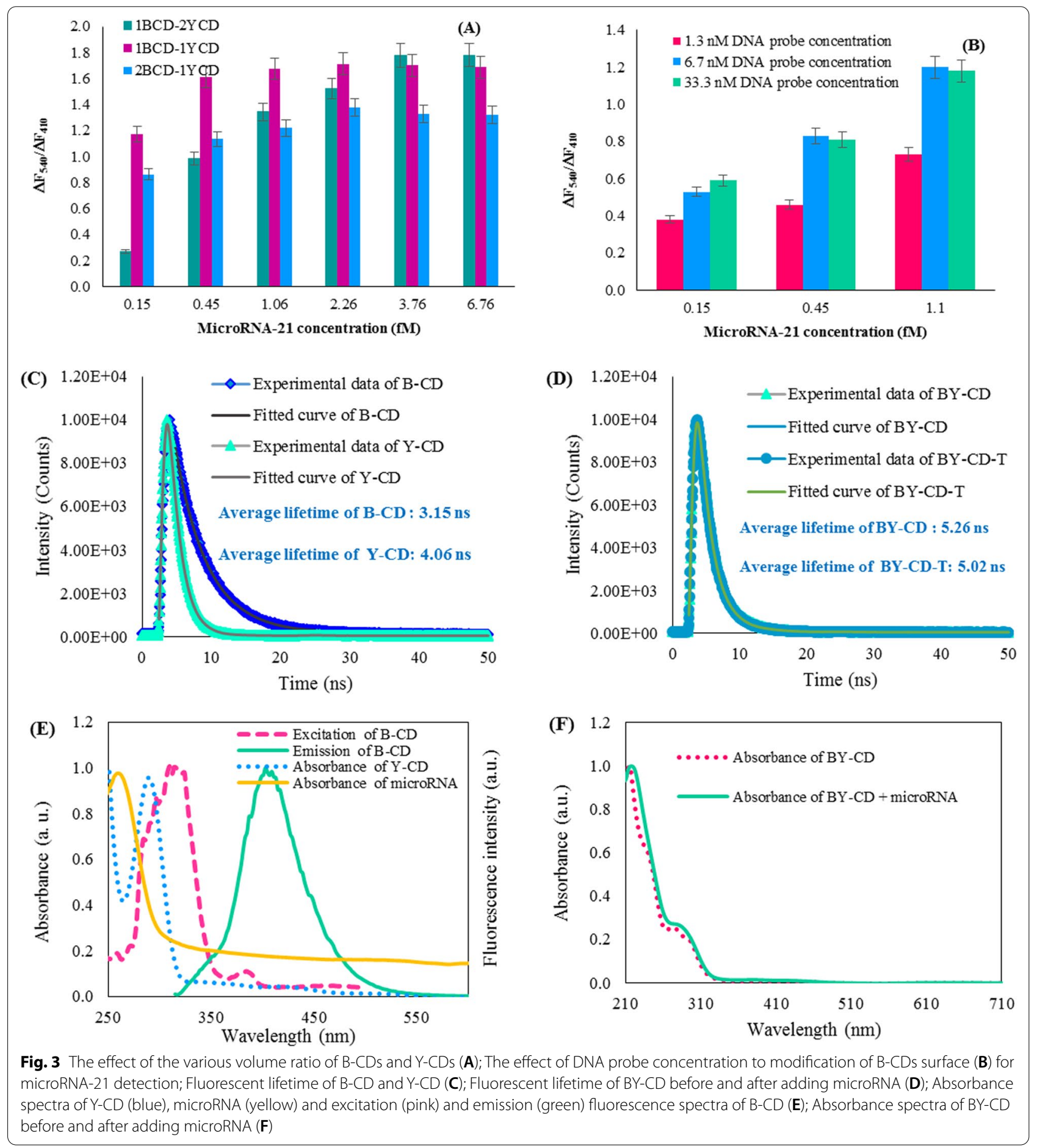


construction of biosensing methods [49]. Here, a DNA probe was exploited for functionalization of B-CDs as the microRNA-21 sensing probe to enable a great number of DNA probes to hybridize with target microRNA-21 with improved probe availability and high sensitivity. Moreover, the functionalization of DNA probes onto B-CDs surface was comprehended, via amidization method among $-\mathrm{COOH}$ groups on $\mathrm{B}-\mathrm{CDs}$ and $-\mathrm{NH}_{2}$ modified DNA probes [50]. As shown in Fig. 2B and D, absorbance and fluorescence spectra exhibited the binding between DNA probe and B-CDs. As shown in Fig. 3B, the effect of various amounts of DNA probes (1.3, 6.7, and $33.3 \mathrm{nM}$ ) was examined for modification of B-CDs surface and the best fluorescence response was obtained for a concentration of $6.7 \mathrm{nM}$ of DNA probes. Therefore, $6.7 \mathrm{nM}$ was selected as the optimal amount of the DNA probe. Furthermore, the fact that the stability of the assay is a significant factor affecting the reproducibility and accuracy of fluorescence measurement is clear. Therefore, the stability of the aqueous solution of BY-CDs and upon addition of microRNA-21 to the BY-CDs system was investigated (Additional file 1: Fig. S4a-d). The fluorescence intensity ratios $\left(\mathrm{F}_{540} / \mathrm{F}_{410}\right)$ were calculated throughout 60 min that the results revealed the signal remained almost constant. To guarantee a good interaction between probe and target, the fluorescence response was measured within a reaction time of $20 \mathrm{~min}$.

\section{Analytical performance of the designed biosensor}

Under optimal conditions, the sensing performance of BY-CDs assay for microRNA-21 detection was investigated. As shown in Fig. 2D, B-CDs displayed a maximum FL emission at $415 \mathrm{~nm}$ and a shoulder at $520 \mathrm{~nm}$ when excited at $360 \mathrm{~nm}$. Upon addition of $15 \mu \mathrm{g} \mathrm{mL}$ of Y-CDs to $15 \mu \mathrm{g} \mathrm{mL}{ }^{-1}$ of DNA functionalized B-CDs, two fluorescence signals can be observed at $410 \mathrm{~nm}$ and $540 \mathrm{~nm}$ under $360 \mathrm{~nm}$ excitation. As can be seen in Fig. 3C, D, the average fluorescence lifetime of probe $\mathrm{B}$-CDs before and after the addition of Y-CDs were $3.15 \mathrm{~ns}$ and $5.61 \mathrm{~ns}$, respectively. Therefore, the fluorescence behavior change of the system can be interpreted as a result of the altered local environment by the interaction between B-CDs and Y-CDs. After the addition of microRNA-21, the fluorescence intensity decreased at $410 \mathrm{~nm}$ while the enhanced fluorescence at $540 \mathrm{~nm}$ can be detected. The sensing mechanism was investigated using absorbance, fluorescence, and lifetime decay experiments. As can be observed in Fig. 3E, the absorption spectrum of microRNA overlapped with the excitation spectrum of the B-CDs. Therefore, the possible fluorescence quenching mechanism can be owing to the inner filter effect (IFE). To verify the IFE, the average fluorescence lifetime of the fluorophore was measured in the absence and the presence of microRNAs (Fig. 3D). The values were calculated to be 5.26 and $5.02 \mathrm{~ns}$, respectively. Since the average amount of lifetime remains almost unchanged, the mechanism can be the IFE. Furthermore, the absorption spectra of the BY-CDs before and after microRNA addition can be the best technique to discriminate between the IFE and static processes. Since the absorption spectrum of the BY-CDs would not alter (Fig. 3F), suggested that fluorescence quenching is because of the IFE rather than the static process $[51,52]$. The specific binding of DNA probe functionalized B-CDs to complementary microRNA-21 target induced perturbations of probe structure and led to an increase of fluorescence intensity at $540 \mathrm{~nm}$. The signal ratio of $\Delta \mathrm{F}_{540} /$ $\Delta \mathrm{F}_{410}$ was applied as a final readout for microRNA-21 determination. The relationship between $\Delta \mathrm{F}_{540} / \Delta \mathrm{F}_{410}$ and logarithm microRNA-21 concentration is displayed in Fig. 3A. The value of $\Delta \mathrm{F}_{540} / \Delta \mathrm{F}_{410}$ linearly depended on the logarithm of the microRNA-21 concentration in the range of $0.15 \mathrm{fM}$ to $2.46 \mathrm{pM}$ with a correlation coefficient of 0.992 . The detection limit for microRNA-21 was calculated to be $50 \mathrm{aM}(\mathrm{S} / \mathrm{N}=3)$. The obtained detection limit is much lower than or comparable to most of the previously reported methods (Table 1). Compared to other ratiometric techniques, not only is this probe extremely sensitive without a complex signal amplification method, but it also possesses the benefit of being affordable and environment-friendly.

Sequence similarity among family members is a remarkable property of microRNA, and distinguishing dissimilarities among members of the microRNA family is a major challenge for microRNA determination. MicroRNAs-155 (T-155), one base-mismatched microRNA-21 (M-21), and one base-mismatched microRNA-155 (M-155) were employed to investigate the selectivity of this assay. As shown in Fig. 4B, a considerable change was recognized in the presence of microRNA-21, whereas other interfering microRNAs make a lower signal response than that of microRNA-21 at the same amount $(0.3 \mathrm{pM})$. However, our consequences displayed that this system reveals high selectivity towards target microRNA-21 and can distinguish other microRNAs with analogous sequence and length.

\section{Application of the miRNA detection assay in serum and cancer cell line samples}

To assess the practical application of the proposed system, target microRNA detected in cancer cells and serum samples. Usually, the concentration of microRNA in biological samples is not adequate to assess microRNA since circulating microRNAs are present at femtomolar concentrations or even lower levels in the blood samples [57]. The appropriate amounts of microRNA-21 (0.15 
Table 1 Nanomaterial-based ratiometric sensors for determination of microRNA

\begin{tabular}{|c|c|c|c|c|c|}
\hline Detection technique & Micro/Nanomaterials & Target & Linear range & Detection limit & References \\
\hline Electrochemical & Black phosphorus nanosheets & MicroRNA-3123 & $2 \mathrm{pM}$ to $2 \mu \mathrm{M}$ & $0.3 \mathrm{pM}$ & {$[20]$} \\
\hline Electrochemical & Au NPs & MicroRNA-141 & $0.1 \mathrm{fM}$ to $100 \mathrm{pM}$ & $11 \mathrm{aM}$ & [53] \\
\hline Electrochemical & Magnetic beads & MicroRNA-21 & $1 \mathrm{pM}$ to $10 \mathrm{nM}$ & $1 \mathrm{pM}$ & {$[56]$} \\
\hline Electrochemiluminescence & $\begin{array}{l}\text { Au NPs functionalized g- } \mathrm{C}_{3} \mathrm{~N}_{4} \text { NS nano- } \\
\text { hybrid (Au-g- } \mathrm{C}_{3} \mathrm{~N}_{4} \mathrm{NH} \text { ) }\end{array}$ & MicroRNA-21 & $1.0 \mathrm{fM}$ to $1.0 \mathrm{nM}$ & $0.5 \mathrm{fM}$ & [21] \\
\hline Chemiluminescence & Graphene oxide quantum dots (GOQD) & MicroRNA-21 & 0.005 to $50 \mathrm{pM}$ & $1.7 \mathrm{fM}$ & [22] \\
\hline SERS & Silica@Au nanoflower (Si@AuNF) & MicroRNA-122 & $10 \mathrm{aM}$ to $100 \mathrm{pM}$ & $7.75 \mathrm{aM}$ & [23] \\
\hline Ratiometric fluorescence & $\begin{array}{l}\text { Boron doped g- } \mathrm{C}_{3} \mathrm{~N}_{4} \text { nanosheets } \\
\text { (BCNNS) \& copper nanocluster (CuNC) }\end{array}$ & MicroRNA-582-3p & 0.2 to $1.0 \mathrm{pM}$ & $12.0 \mathrm{fM}$ & [25] \\
\hline Ratiometric fluorescence & Carbon dots & MicroRNA-21 & $0 \mathrm{fM}$ to $500 \mathrm{fM}$ & $3 \mathrm{pM}$ & {$[38]$} \\
\hline Ratiometric fluorescence & Carbon dots & MicroRNA-21 & 50 to $10,000 \mathrm{pM}$ & $1 \mathrm{pM}$ & [26] \\
\hline $\begin{array}{l}\text { Fluorescence resonance } \\
\text { energy transfer (FRET) }\end{array}$ & $\begin{array}{l}\text { Conjugated polymer (CCP) } \\
\text { \& fluorescein }\end{array}$ & let-7a family & 0.2 to $100 \mathrm{pM}$ & $0.08 \mathrm{pM}$ & [54] \\
\hline FRET & Fluorescence dyes Cy3,Cy3.5, Cy5 & $\begin{array}{l}\text { MicroRNA-155, micro- } \\
\text { RNA-182, and micro- } \\
\text { RNA-197 }\end{array}$ & 0.02 to $10 \mathrm{nM}$ & $\begin{array}{l}18 \mathrm{pM}, \\
12 \mathrm{pM} \text {, and } 11 \mathrm{pM}\end{array}$ & {$[55]$} \\
\hline Ratiometric fluorescence & Carbon dots & MicroRNA-21 & $0.15 \mathrm{fM}$ to $2.46 \mathrm{pM}$ & $50 \mathrm{aM}$ & This work \\
\hline
\end{tabular}

and $0.5 \mathrm{fM}$ ) were spiked into $1.0 \%(\mathrm{v} / \mathrm{v})$ healthy human serum and quantified by the ratiometric fluorescence biosensor. Acceptable recovery rates (93.3-98.0\%) and relative standard deviations (RSD \%) (2.9-5.4\%) were acquired for spiked serum samples (Table 2), representing the favorable potential of the presented ratiometric assay for detecting microRNA-21 in real human serum.

Further investigation of the ratiometric fluorescence nanoprobe in response to varying cellular components, such as MCF-7 cell lines, exhibited high selectivity to microRNA-21 (Fig. 4C). Moreover, the nanoprobe provided decreasing fluorescence intensity at $410 \mathrm{~nm}$ and increasing fluorescence intensity at $540 \mathrm{~nm}$ with an enhanced concentration of microRNA-21 in the cell extraction samples from the MCF-7. Figure $4 \mathrm{C}$ shows that the linear relationship between $\Delta \mathrm{F}_{540} / \Delta \mathrm{F}_{410}$ and the concentration of microRNA-21 extracted from the MCF-7 cells from 3000 to 45,000 (cell mL ${ }^{-1}$ ). The detection limit was calculated to be 300 cell $\mathrm{mL}^{-1}$ ( 3 cells in 10 $\mu \mathrm{L}$ of the injected sample) at $\mathrm{S} / \mathrm{N}$ of 3 . These results demonstrated that this ratiometric nanoprobe holds great potential for microRNA analysis in different tumor cells, which is of great significance in biomedical research and clinical diagnosis.

\section{MicroRNA-21 imaging in MCF-7 cells}

Dual-emissive CDs with outstanding water solubility and great optical features are anticipated to be a suitable fluorescent option for bioimaging. To investigate the bioimaging applications of CDs in MCF-7 cells, the relative viability of MCF-7 cancer cells exposed to BY-CDs was assessed by MTT assay at 545/630 nm. The results proved that the BY-CDs were not toxic to MCF-7 cells because more than $95 \%$ of the MCF-7 cells were viable when the concentration of the BY-CDs was less than $1.0 \mathrm{mg} \mathrm{mL}^{-1}$ (Additional file 1: Fig. S5). These MTT consequences reveal that modified BY-CDs can be exploited as nontoxic labels for cellular imaging usages. The reaction time of MCF-7 cancer cell imaging has been adjusted for $24 \mathrm{~h}$. MCF-7 cancer cells treated with BY-CDs did not exhibit considerable changes in shape. As shown in Fig. 5A-L, robust blue, green, yellow, and red photoluminescence on MCF-7 cell membranes demonstrated that BY-CDs had moved in the cells and that fluorescence features had been

Table 2 Results from ratiometric nanobioensor for detection of microRNA-21 in serum samples

\begin{tabular}{llllll}
\hline Sample & Measured (fM) & Spiked (fM) & Found (fM) & Recovery \% & RSD (\%, $\mathbf{n = 3}$ \\
\hline $\mathbf{1}$ & 0.13 & 0.15 & 0.265 & 90.0 & 2.9 \\
$\mathbf{2}$ & 0.16 & 0.50 & 0.62 & 98.0 & 5.4 \\
& & 0.15 & 0.305 & 96.7 & 5.1 \\
\end{tabular}




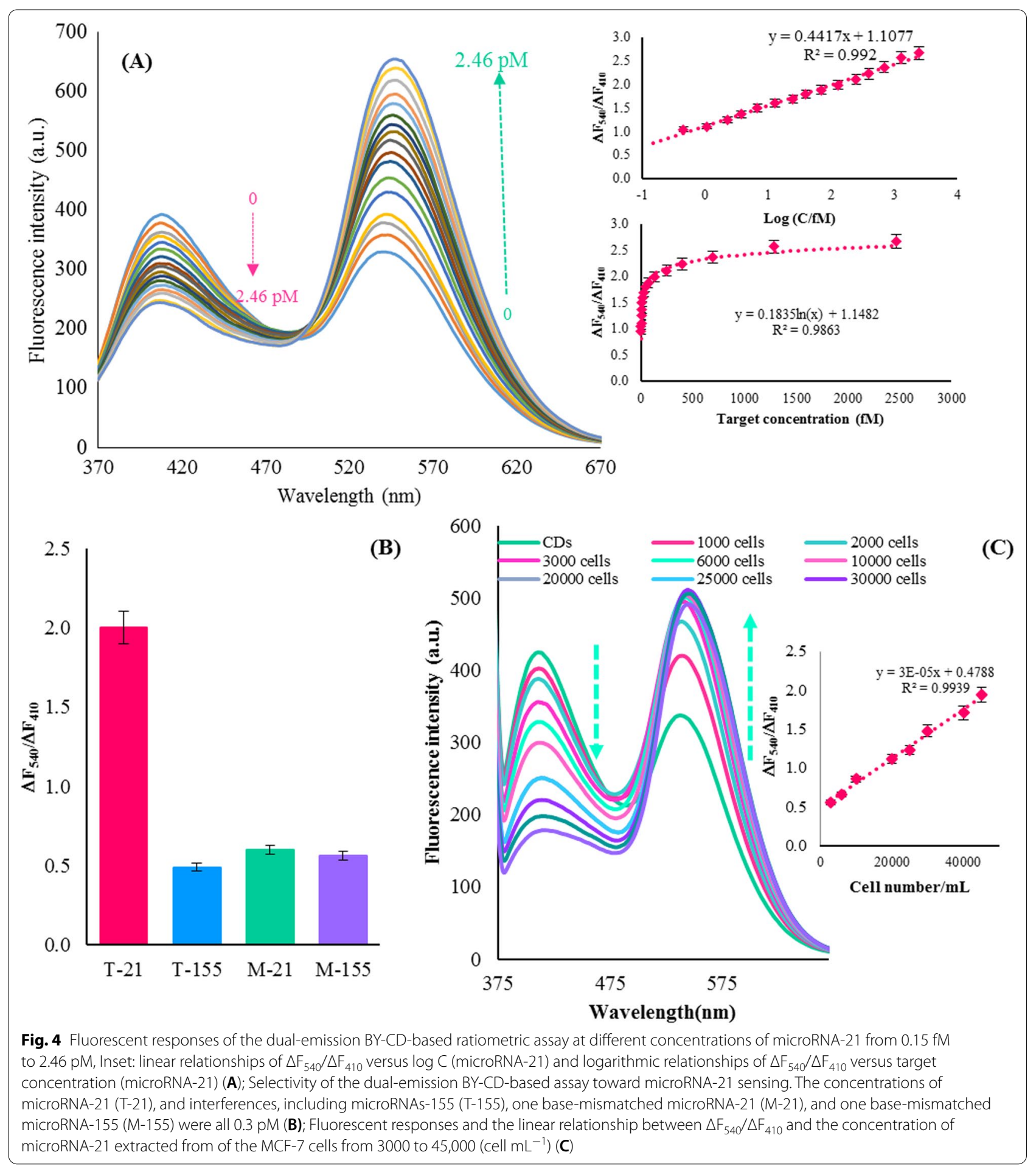

preserved in the cellular medium, while no radiant light in the core is not visible. The images revealed that MCF-7 cells are well labeled with CDs and strong multicolor fluorescence could be proposed the applicability of BY-CDs in bioimaging.

\section{Applications in real-sample analysis on microfluidics}

Profited from the small sample volumes, ease of incorporation, fast analyses time, and high movability presented by microfluidics, microfluidic chips are one of the most remarkable technologies, which have 

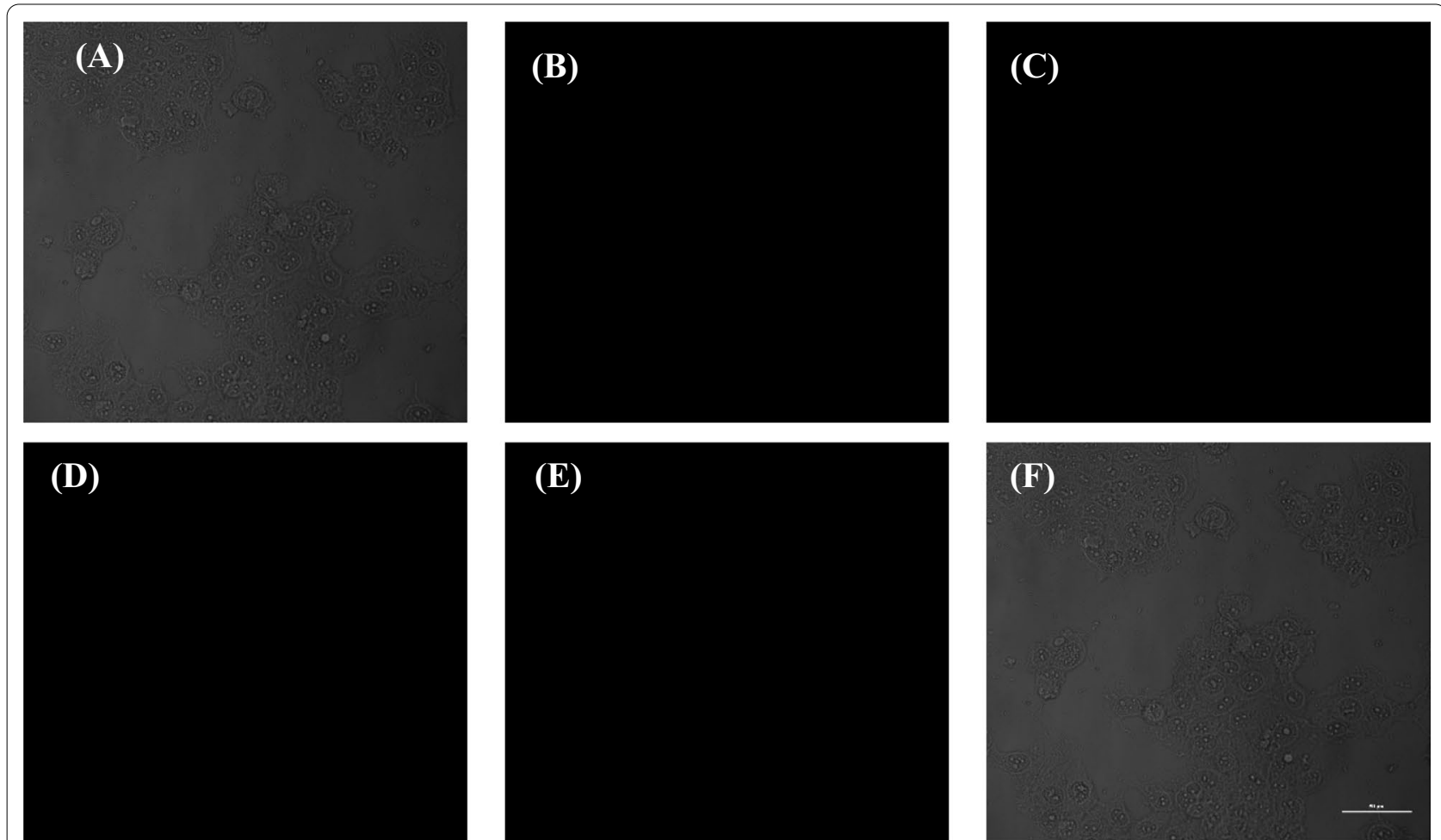

(E)
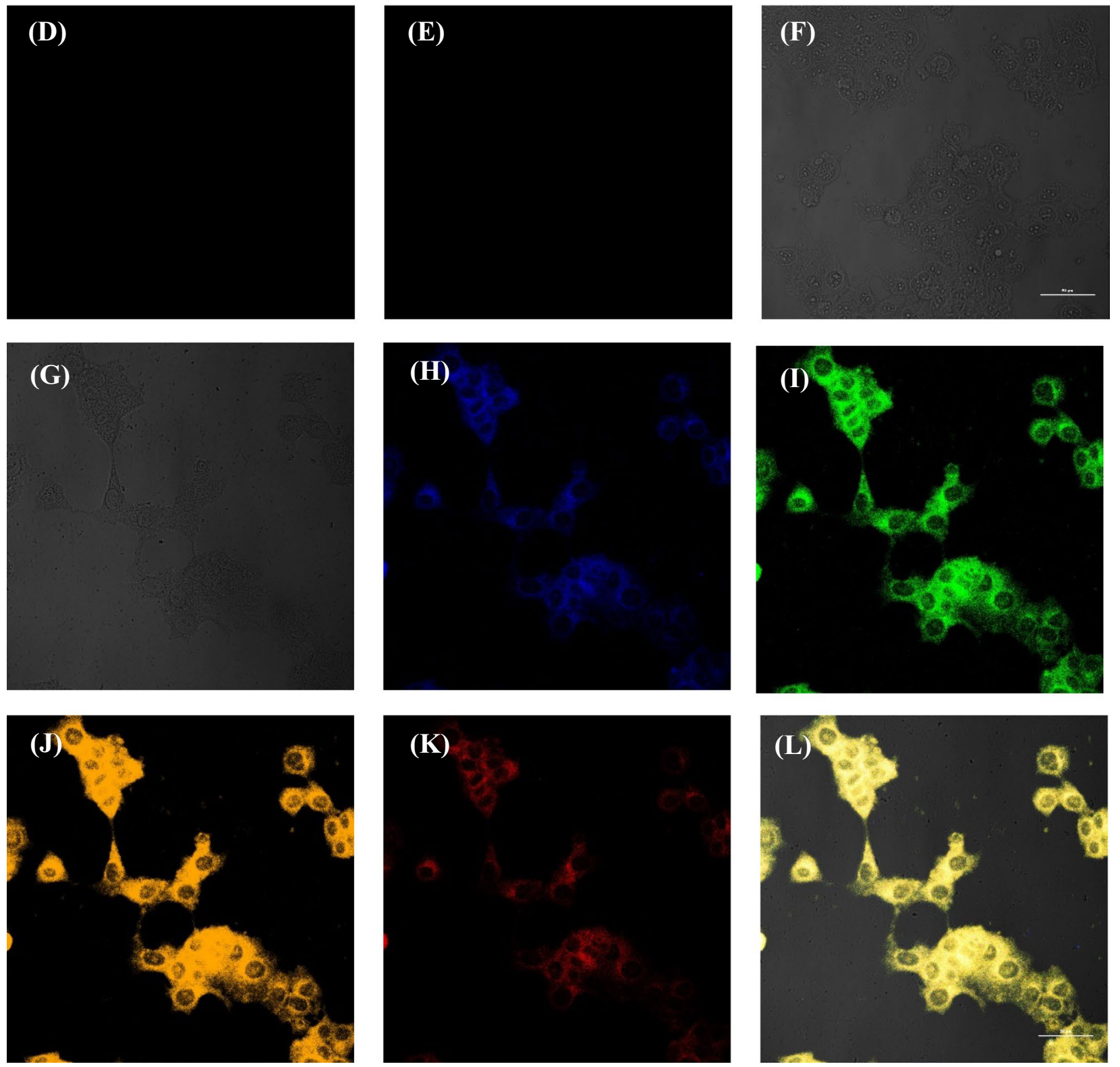

Fig. 5 Confocal laser scanning microscopic images of MCF-7: control (A-F) cells and cells treated with $1.0 \mathrm{mg} \mathrm{mL}^{-1}$ of BY-CDs $(\mathbf{G}-\mathbf{L})$ excitation by bright field $(\mathbf{A}, \mathbf{G})$, Blue $(\mathbf{B}, \mathbf{H})$, Green $(\mathbf{C}, \mathbf{I}$, Yellow $(\mathbf{D}, \mathbf{J})$, Red $(\mathbf{E}, \mathbf{K})$ and Merge $(\mathbf{F}, \mathbf{L})$ 


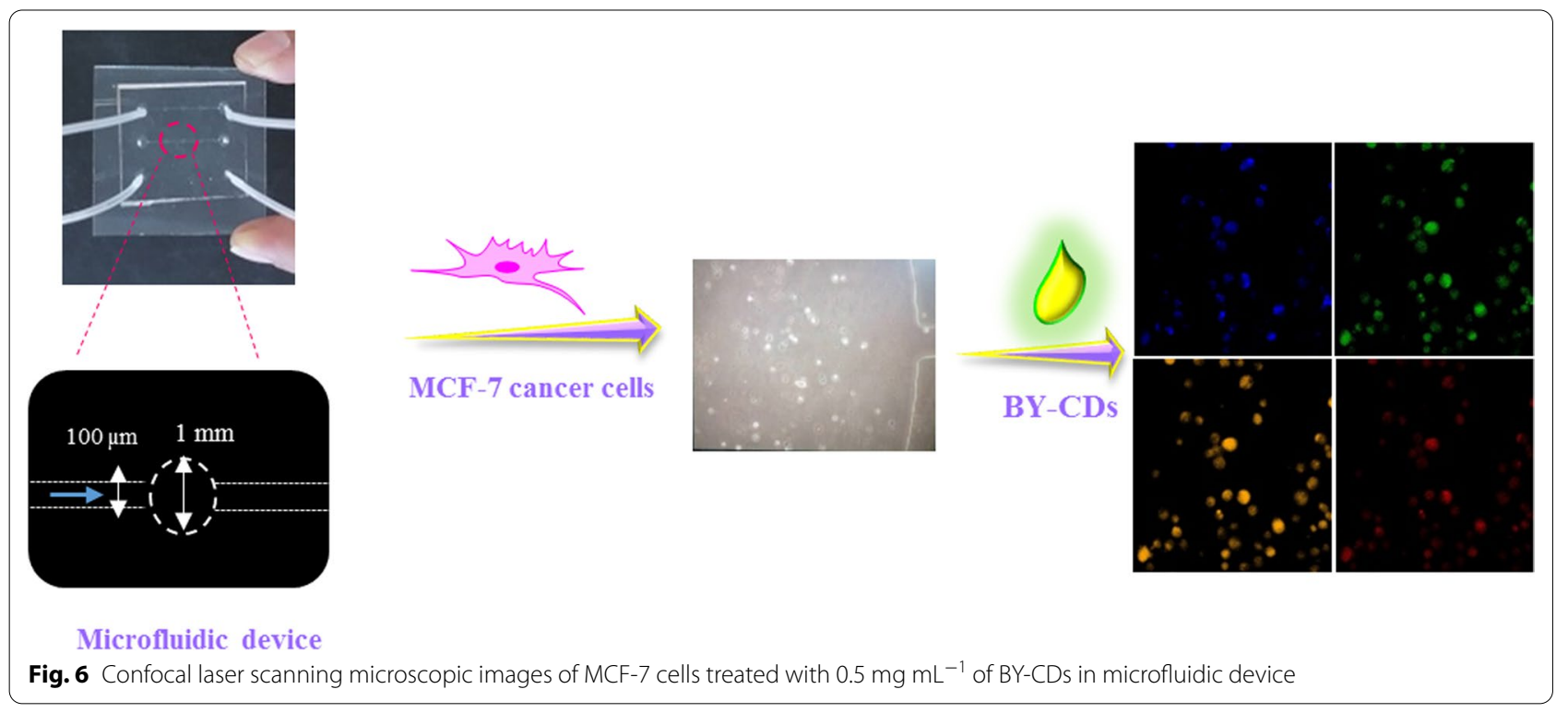

been combined with fluorescence biosensor methods to increase their efficiency [58]. To increase the user accessibility, the MCF-7 cells were applied in a microfluidic device to allow imaging under a confocal fluorescence microscope. MCF-7 cells were introduced into the channels at a flow rate of $10 \mu \mathrm{L} \mathrm{min}{ }^{-1}$ to assess the robustness of our procedures. After $24 \mathrm{~h}$ incubation at $37{ }^{\circ} \mathrm{C}$, BY-CDs solution at a concentration of $0.5 \mathrm{mg} \mathrm{mL}^{-1}$ (dissolved in DMEM) was inserted into the microfluidic. After $5 \mathrm{~h}$, the cancer cells were washed with PBS then fluorescence image analysis was attained under various excitation filters. As can be seen in Fig. 6, the MCF-7 cells answered to the full spectrum of excitation light by emitting signals. Furthermore, the efficiency of the biosensor in the microfluidic chip was preserved. The high portability, speed of analysis, and low sample consumption make this tool an ideal format for rapid point-of-care diagnosis methods.

\section{Conclusions}

In summary, a highly sensitive ratiometric fluorescence assay was developed for microRNA-21 detection at aM concentration range in serum samples and also in MCF cell lines using blue and yellow carbon dots (B-CDs, $\mathrm{Y}-\mathrm{CDs}$, and $\mathrm{F}_{540 \mathrm{~nm}} / \mathrm{F}_{410 \mathrm{~nm}}$ ) as fluorophores. The proposed fluorescent nano biosensor has become a robust approach in analytical sensing owing to its rapid response, great sensitivity, and technical simplicity. Furthermore, due to the low toxicity of CDs, we constructed a microfluidic device for fluorescent imaging of microRNA in MCF-7 cells using DNA probe conjugated dual emissive CDs. Not only did this nanoprobe provide a highly sensitive procedure for microRNA-21 detection, but it also enabled to distinguish of single-base mismatched microRNAs. Moreover, this procedure effectively evaluated for quantification of microRNA-21 in clinical serum samples. The acceptable recovery and reproducibility results demonstrated that the bioassay provides the possibility of a diagnosis of microRNA-related diseases. Although this assay was utilized for single-analyte detection, our study suggested the possibility of developing sensitive, robust biosensors for the determination of multiple analytes to meet clinical needs in disease-related microRNA.

\section{Supplementary Information}

The online version contains supplementary material available at https://doi. org/10.1186/s12951-022-01274-3.

Additional file 1. Additional informations includes SEM images of CDs, impedance data, UV-vis and fluorescence spectra of B-CD and Y-CD mixture and Cellular cytotoxicity evaluation of the BY-CD toward MCF-7 cells.

\section{Acknowledgements}

We would like to thank Professor Mohamad Reza Ganjali (University of Tehran) and their colleagues Professor Morteza Hossaini and Dr. Foad Salehnia for lifetime fluorescence measurements.

\section{Authors' contributions}

SM performed experiments, data analyses and wrote the manuscript; AS performed writing - review and editing, supervision, project administration, funding acquisition; ZH contributed to doing cell culture experiments and celIular cytotoxicity test; FG helped for designing microfluidic; KM supervised for imaging section. All authors read and approved the final manuscript.

\section{Funding}

S.M. thanks the support from the research office of the University of Kurdistan under the postdoc program (Grant number 98.11.2533). The Iranian Nanotechnology Initiative support is also acknowledged. 


\section{Availability of data and materials}

All data analyzed during this study are included in this published article.

\section{Declarations}

\section{Ethics approval and consent to participate}

Not applicable.

\section{Consent for publication}

All authors of this work consent to the publication of the paper.

\section{Competing interests}

The authors declare that they have no known competing financial interests or personal relationships that could have appeared to influence the work reported in this paper.

\section{Author details}

1 Department of Chemistry, University of Kurdistan, 66177-15175 Sanandaj, Iran. ${ }^{2}$ Research Center for Nanotechnology, University of Kurdistan, 66177-15175 Sanandaj, Iran. ${ }^{3}$ Medical Biology Research Center, Kermanshah University of Medical Sciences, Kermanshah, Iran. ${ }^{4}$ Nanoscale Physics Device Lab (NPDL), Department of Physics, University of Kurdistan, 66177-15275 Sanandaj, Iran.

\section{Received: 12 October 2021 Accepted: 17 January 2022}

Published online: 08 February 2022

\section{References}

1. Saultz JN, Freud AG, Mundy-Bosse BL. MicroRNA regulation of natural killer cell development and function in leukemia. Mol Immunol. 2019:115:12-20.

2. Machado IF, Teodoro JS, Palmeira CM, Rolo AP. miR-378a: a new emerging microRNA in metabolism cell. Mol Life Sci. 2020;77:1947-58.

3. Zhang WF, Xiong YW, Zhu TT, Xiong AZ, Bao HH, Cheng XS. MicroRNA let$7 \mathrm{~g}$ inhibited hypoxia-induced proliferation of PASMCs via $G_{0} / G_{1}$ cell cycle arrest by targeting c-myc. Life Sci. 2017;170:9-15.

4. Amado T, Amorim A, Enguita FJ, Romero PV, Inácio D, de Miranda MP, Winter SJ, Simas JP, Krueger A, Schmolka N, Silva-Santos B, Gomes AQ. MicroRNA-181a regulates IFN- $\gamma$ expression in effector CD8 ${ }^{+} \mathrm{T}$ cell differentiation. J Mol Med. 2020;98:309-20.

5. Yang X, Zhang M, Wei M, Wang A, Deng Y, Cao H. MicroRNA-216a inhibits neuronal apoptosis in a cellular Parkinson's disease model by targeting Bax. Metab Brain Dis. 2020;35:627-35.

6. Vasu S, Kumano K, Darden CM, Rahman I, Lawrence MC, Naziruddin B. MicroRNA signatures as future biomarkers for diagnosis of diabetes states. Cells. 2019:8:1533-64.

7. López P, Girardi E, Pfeffer S. Importance of cellular microRNAs in the regulation of viral infections. Med Sci. 2019;35(8-9):667-73.

8. Camacho L, Silva CS, Hanig JP, Schleimer RP, George NI, Bowyer JF. Identification of whole blood mRNA and microRNA biomarkers of tissue damage and immune function resulting from amphetamine exposure or heat stroke in adult male rats. PLoS ONE. 2019;14(2): e0210273. https:// doi.org/10.1371/journal.pone.0210273.

9. Yeh M, Oh CS, Yoo JY, Kaur B, Lee TJ. Pivotal role of microRNA-138 in human cancers. Am J Cancer Res. 2019:9(6):1118-26.

10. Tian L, Qian K, Qi J, Liu Q, Yao C, Song W, Wang Y. Gold nanoparticles superlattices assembly for electrochemical biosensor detection of microRNA-21. Biosens Bioelectron. 2018:99:564-70.

11. Li X, Dou B, Yuan R, Xiang Y. Mismatched catalytic hairpin assembly and ratiometric strategy for highly sensitive electrochemical detection of microRNA from tumor cells. Sensor Actuat B- Chem. 2019;286:191-7.

12. Labib M, Khan N, Ghobadloo SM, Cheng J, Pezacki JP, Berezovski MV. Three-mode electrochemical sensing of ultralow MicroRNA levels. J Am Chem Soc. 2013;135:3027-38.

13. Tanriverdi K, Kucukural A, Mikhalev E, Tanriverdi SE, Lee R, Ambros VR, Freedman JE. Comparison of RNA isolation and associated methods for extracellular RNA detection by high-throughput quantitative polymerase chain reaction. Anal Biochem. 2016:501:66-74.
14. Várallyay E, Burgyán J, Havelda Z. MicroRNA detection by northern blotting using locked nucleic acid probes. Nat protoc. 2008;3(2):190-6.

15. Li W, Ruan K. MicroRNA detection by microarray. Anal Bioanal Chem. 2009;394(4):1117-24

16. Hao N, Dai PP, Yu T, Xu JJ, Chen HY. (2015) A dual target-recycling amplification strategy for sensitive detection of microRNAs based on duplex-specific nuclease and catalytic hairpin assembly. Chem Commun. 2015;51:13504-7.

17. Chen $Y$, Xiang $Y$, $Y$ uan $R$, Chai $Y$. Intercalation of quantum dots as the new signal acquisition and amplification platform for sensitive electrochemiluminescent detection of microRNA. Anal Chim Acta. 2015:891:130-5.

18. Li L, Chen Y, Zhu JJ. Recent advances in electrochemiluminescence analysis. Anal Chem. 2017:89(1):358-71.

19. Luo L, Wang L, Zeng L, Wang Y, Weng Y, Liao Y, Chen T, Xia Y, Zhang J, Chen J. A ratiometric electrochemical DNA biosensor for detection of exosomal MicroRNA. Talanta. 2020;207:120298.

20. Sun $Y$, Jin $H$, Jiang $X$, Gui R. Black phosphorus nanosheets adhering to thionine-doped 2D MOF as a smart aptasensor enabling accurate capture and ratiometric electrochemical detection of target microRNA. Sens Actuat B- Chem. 2020;309:127777.

21. Chen QM, Shen YZ, Li MX, Zhang ZL, Zhao W, Xu JJ, Chen HY. (2016) Dual-wavelength electrochemiluminescence ratiometry based on resonance energy transfer between Au nanoparticles functionalized $\mathrm{g}-\mathrm{C} 3 \mathrm{~N} 4$ nanosheet and Ru (bpy) ${ }_{3}{ }^{2+}$ for microRNA detection. Anal Chem. 2016;88(1):937-44

22. Chen D, Wen S, Peng R, Gong Q, Fei J, Fu Z, Weng C, Liu M. A triple signal amplification method for chemiluminescent detection of the cancer marker microRNA-21. Microchim Acta. 2019;186(7):410-7.

23. He $Y$, Yang $X$, Yuan $R$, Chai $Y$. A novel ratiometric SERS biosensor with one Raman probe for ultrasensitive microRNA detection based on DNA hydrogel amplification. J Mater Chem B. 2019;7(16):2643-7.

24. Zhang S, Xu S, Li X, Ma R, Cheng G, Xue Q, Wang H. Double-signal mode based on metal-organic framework coupled cascaded nucleic acid circuits for accurate and sensitive detection of serum circulating miRNAs. Chem Commun. 2020:56:4288-91.

25. Wang Y, Wu N, Guo F, Gao R, Yang T, Wang J. g-C3N4 nanosheet-based ratiometric fluorescent probes for the amplification and imaging of miRNA in living cells. J Mater Chem B. 2019;7:7566-73.

26. Wang Z, Xue Z, Hao X, Miao C, Zhang J, Zheng Y, Zheng Z, Lin X, Weng $S$. Ratiometric fluorescence sensor based on carbon dots as internal reference signal and T7 exonuclease-assisted signal amplification strategy for microRNA-21 detection. Anal Chim Acta. 2020;1103:212-9.

27. Wang $S$, Wang $L, X u X$, Li X, Jiang W. $\mathrm{MnO}_{2}$ nanosheet-mediated ratiometric fluorescence biosensor for MicroRNA detection and imaging in living cells. Anal Chim Acta. 2019;1063:152-8.

28. Zheng W, Yao L, Teng J, Yan C, Qin P, Liu G, Chen W. Lateral flow test for visual detection of multiple MicroRNAs. Sens Actuat B- Chem. 2018;264:320-6.

29. Bigdeli A, Ghasemi F, Abbasi-Moayed S, Shahrajabian M, FahimiKashani N, Jafarinejad S, Nejad MA, Hormozi-Nezhad MR. Ratiometric fluorescent nanoprobes for visual detection: design principles and recent advances-a review. Anal Chim Acta. 2019;1079:30-58.

30. Salimi A, Kavosi B, Navaee A. Amine-functionalized graphene as an effective electrochemical platform toward easily miRNA hybridization detection. Measurement. 2019;143:191-8.

31. Mohammadi S, Salimi A. Fluorometric determination of microRNA-155 in cancer cells based on carbon dots and $\mathrm{MnO}_{2}$ nanosheets as a donor-acceptor pair. Microchim Acta. 2018;185(8):372-81.

32. Majd SM, Salimi A, Ghasemi F. An ultrasensitive detection of miRNA155 in breast cancer via direct hybridization assay using two-dimensional molybdenum disulfide field-effect transistor biosensor. Biosens Bioelectron. 2018;105:6-13.

33. Chen J, Jin T, Li J, Zhang X, Liu F, Tan C, Tan Y. One-pot simultaneous detection of multiple DNA and MicroRNA by integrating the cationicconjugated polymer and nuclease-assisted cyclic amplification. ACS Appl Bio Mater. 2021;4:820-8.

34. Walling MA, Novak JA, Shepard JRE. Quantum dots for live cell and in vivo imaging. Int J Mol Sci. 2009;10(2):441-91.

35. Yang ST, Cao L, Luo PG, Lu F, Wang X, Wang H, Meziani MJ, Liu Y, Qi G, Sun YP. Carbon dots for optical imaging in vivo. J Am Chem SoC. $2009 \cdot 131: 11308-9$ 
36. Pirsaheb M, Mohammadi S, Salimi A. Current advances of carbon dots based biosensors for tumor marker detection, cancer cells analysis and bioimaging. TrAC Trends Anal Chem. 2019;115:83-99.

37. Ahlawat J, Barroso GG, Asil SM, Alvarado M, Armendariz I, Bernal J, Carabaza X, Chavez S, Cruz P, Escalante V, Estorga S, Fernandez D, Lozano C, Marrufo M, Ahmad N, Negrete S, Olvera K, Parada X, Portillo B, Ramirez A, Ramos R, Rodriguez V, Rojas P, Romero J, Suarez D, Urueta G, Viel S, Narayan M. Nanocarriers as potential drug delivery candidates for overcoming the blood-brain barrier: challenges and possibilities. ACS Omega. 2020;5(22):12583-95.

38. Gogoi S, Devi R, Dutta HS, Bordoloi M, Khan R. Ratiometric fluorescence response of a dual light emitting reduced carbon dot/ graphene quantum dot nanohybrid towards As (iii). J Mater Chem C. 2019;7(33):10309-17.

39. Ahmad N, Bhatnagar S, Ali SS, Dutta R. Phytofabrication of bioinduced silver nanoparticles for biomedical applications. Int J Nanomed. 2015;10:7019.

40. Jalili R, Khataee A, Rashidi MR, Luque R. Dual-colored carbon dot encapsulated metal-organic framework for ratiometric detection of glutathione. Sensor Actuat B- Chem. 2019;297:126775-82.

41. Xia Y, Wang L, Li J, Chen X, Lan J, Yan A, Yan L, Yang S, Yang H, Chen J. A ratiometric fluorescent bioprobe based on carbon dots and acridone derivate for signal amplification detection exosomal microRNA. Anal Chem. 2018;90(15):8969-76.

42. Rhee SW, Taylor AM, Tu CH, Cribbs DH, Cotman CW, Jeon NL. Patterned cell culture inside microfluidic devices. Lab Chip. 2005;5(1):102-7.

43. Vedamalai M, Periasamy AP, Wang CW, Tseng YT, Ho LC, Shih CC, Chang HT. Carbon nanodots prepared from o-phenylenediamine for sensing of $\mathrm{Cu}^{2+}$ ions in cells. Nanoscale. 2014;6(21):13119-25.

44. Xia C, Zhu S, Feng T, Yang M, Yang B. Evolution and synthesis of carbon dots: from carbon dots to carbonized polymer dots. Adv Sci. 2019;6(23):1901316.

45. Wang J, Peng F, Lu Y, Zhong Y, Wang S, Xu M, Ji X, Su Y, Liao L, He Y. Largescale green synthesis of fluorescent carbon nanodots and their use in optics applications. Adv Opt Mater. 2015;3(1):103-11.

46. Li L, Shi L, Jia J, Eltayeb O, Lu W, Tang Y, Dong C, Shuang S. Dual photoluminescence emission carbon dots for ratiometric fluorescent GSH sensing and cancer cell recognition. ACS Appl Mater Interfaces. 2020;12(16):18250-7.

47. Hamd-Ghadareh S, Salimi A, Fathi F, Bahrami S. An amplified comparative fluorescence resonance energy transfer immunosensing of CA125 tumor marker and ovarian cancer cells using green and economic carbon dots for bio-applications in labeling, imaging and sensing. Biosens Bioelectron. 2017;96:308-16.

48. Chan KK, Yap SHT, Yong KT. Biogreen synthesis of carbon dots for biotechnology and nanomedicine applications. Nano-micro let. 2018;10(4):1-46.

49. Han S, Liu W, Yang S, Wang R. Facile and label-free electrochemical biosensors for microRNA detection based on DNA origami nanostructures. ACS Omega. 2019;4(6):11025-31.

50. Pirsaheb M, Mohammadi S, Salimi A, Payandeh M. Functionalized fluorescent carbon nanostructures for targeted imaging of cancer cells: a review. Microchim Acta. 2019;186(4):231.

51. Zu F, Yan F, Bai Z, Xu J, Wang Y, Huang Y, Zhou X. The quenching of the fluorescence of carbon dots: a review on mechanisms and applications. Microchim Acta. 2017;184(7):1899-914.

52. Gunjal DB, Gurav YM, Gore AH, Naik VM, Waghmare RD, Patil CS, Sohn D, Anbhule PV, Shejwal RV, Kolekar GB. Nitrogen doped waste tea residue derived carbon dots for selective quantification of tetracycline in urine and pharmaceutical samples and yeast cell imaging application. Opt Mater. 2019;2019(98):109484.

53. Yuan YH, Chi BZ, Wen SH, Liang RP, Li ZM, Qiu JD. Ratiometric electrochemical assay for sensitive detecting microRNA based on dual-amplification mechanism of duplex-specific nuclease and hybridization chain reaction. Biosens Bioelectron. 2018;102:211-6.

54. Zhang J, Zhao L, Dong L, Nie X, Cheng Y. Integration of T7 exonucleasetriggered amplification and cationic conjugated polymer biosensing for highly sensitive detection of microRNA. Talanta. 2018;190:475-9.

55. Liu Y, Wei M, Li Y, Liu A, Wei W, Zhang Y, Liu S. Application of spectral crosstalk correction for improving multiplexed MicroRNA detection using a single excitation wavelength. Anal Chem. 2017;89(6):3430-6.
56. Boriachek K, Umer M, Nazmul Islam M, Gopalan V, Lam AK, Nguyen NT, Shiddiky MJA. An amplification-free electrochemical detection of exosomal miRNA-21 in serum samples. Analyst. 2018;143:1662-9.

57. Moazampour M, Zare HR, Shekari Z. Femtomolar determination of an ovarian cancer biomarker (miR-200a) in blood plasma using a label free electrochemical biosensor based on L-cysteine functionalized ZnS quantum dots. Anal Methods. 2021;13(17):2021-9.

58. Liao Z, Zhang Y, Li Y, Miao Y, Gao S, Lin F, Deng Y, Geng L. Microfluidic chip coupled with optical biosensors for simultaneous detection of multiple analytes: a review. Biosens Bioelectron. 2019;126:697-706.

\section{Publisher's Note}

Springer Nature remains neutral with regard to jurisdictional claims in published maps and institutional affiliations.
Ready to submit your research? Choose BMC and benefit from:

- fast, convenient online submission

- thorough peer review by experienced researchers in your field

- rapid publication on acceptance

- support for research data, including large and complex data types

- gold Open Access which fosters wider collaboration and increased citations

- maximum visibility for your research: over $100 \mathrm{M}$ website views per year

At BMC, research is always in progress.

Learn more biomedcentral.com/submissions 